DOI: 10.35340/2308-104X.2019.83-2-05

РОЛЬ МАРКЕТИНГОВИХ ДОСЛІДЖЕНЬ У

ЗАБЕЗПЕЧЕННІ ЕФЕКТИВНОЇ РОБОТИ ПІДПРИЕМСТВ

\section{THE ROLE OF MARKETING RESEARCH TO PROVIDE EFFICIENCY OF THE ENTERPRISES}

\author{
ХРАПКІНА В. В., \\ доктр економічних наук, \\ професор, професор кафедри \\ маркетингу та управління \\ бізнесом Національного \\ університету «Києво- \\ Могилянська Академія", \\ КУЗНСЦОВА К. В., \\ магістр Національного \\ університету «Кисво- \\ Могилянська Академія»
}

\author{
KHRAPKINA V., \\ Doctor of Economics, Professor, \\ Professor Department of Marketing \\ and Business Management, National \\ University of «Kyiv-Mohyla \\ Academy», \\ KUZNIETSOVA K., \\ Master's degree student, National \\ University of «Kyiv-Mohyla \\ Academy»
}

Маркетингові дослідження відіграють вагому роль у прийнятті рімення щзодо функціонування підприємства, підсилюючи або спростовуючи аргументи щзодо позииіі управлінців. Відмінною особливістю маркетингового дослідження $\epsilon$, насамперед, виокремлення проблеми, на вирішення якої спрямований подальший процес. Важливим аспектом забезпечення ефективної роботи підприємств є виявлення взаємозв'язку між маркетинговими дослідженнями та результатами господарської діяльності.

У статті проаналізовано ринок маркетингових досліджень України, який, в контексті галузевого розподілу, тяжіє до тендениії зростанню обсягів замовлень в грошовому вимірі. Розглянуто сутність та класифікації маркетингових досліджень, які зумовлюють подальшу ефективність роботи підприємств. Сформульовано визначення маркетингових досліджень та виокремлено групи маркетингових досліджень залежно від предмету дослідження. Зроблено висновки щуодо впливу використання маркетингових досліджень з позииіі сучасного стану украӥнського ринку та отримання прибутку як результату господарської діяльності підприємств.

Ключові слова: маркетингові дослідження; ринок маркетингових досліджень; ринок В2B; ринок В2С; замовники маркетингових досліджень; результат господарської діяльності.

Маркетинговые исследования играют важную роль в проиессе принятия решений, касаюшихся функционирования предприятия, усиливая или опровергая аргументы управленщев. Отличительной чертой маркетинговых исследований является, прежде всего, определение проблемы, на решение которой направлен весь дальнейший прочесс. 
Важным аспектом обеспечения эффективной работы предприятия является выявление взаимосвязи между маркетинговыми исследованиями и результатами деятельности.

В статье проанализирован рынок маркетинговых исследований в Украине, который, в контексте отраслевого распределения, тяготеет к тендениии роста объемов заказов в денежном измерении. Рассмотрень сущиность $u$ классификация маркетинговых исследований, обуславливающие дальнейшую эффективность работь предприятий. Сформулировано определение маркетинговых исследований и выделены группь маркетинговых исследований в зависимости от предмета исследования. Сделаны выводы о влиянии использования маркетинговых исследований с позиции современного состояния украинского рынка и получения прибыли как результата хозяйственной деятельности предприятий.

Ключевые слова: маркетинговые исследования; рынок маркетинговых исследований; рынок B2B; рынок В2C; заказчики маркетинговых исследований; результата хозяйственной деятельности.

The Ukrainian market of marketing research has experienced sharp fluctuations in the dollar equivalent during the last 10 years, but in the hryvnia equivalent it has constantly grown. In order to fully cover the sectoral distribution and further development of trends, the positions of different scholars on the nature and classification of marketing research should be taken into account. An important aspect of ensuring the effective operation of enterprises is the identification of the relationship between marketing research and the results of economic activity.

In the article analyzed the Ukrainian market of marketing research, which, in the context of branch division, tends to increase the volume of orders in monetary terms. The issue and classification of marketing researches, which determine the further efficiency of the enterprises, are considered. The definition of marketing research is formulated, and the groups of marketing researches are distinguished depending on the subject of the research. The conclusions about the influence of marketing research on the position of the current state of the Ukrainian market and profit as a result of economic activity of enterprises are made.

Keywords: marketing research, market of marketing research, $B 2 B$ market, B2C market, customers of marketing research, results of economic activity.

Постановка проблеми. В сучасних умовах господарювання для забезпечення економічного розвитку підприємства змушені постійно контролювати і підвищувати економічну ефективність своєї діяльності. Найважливішою складовою частиною діяльності підприємств, які зацікавлені в досягненні сталого становища або динамічного розвитку, є саме маркетингові дослідження. Оскільки вони потребують виявлення нагальної проблеми щодо операційної, тактичної або стратегічної діяльності об’єкта, та запуску процесу пошуку, збору, систематизації даних, їхню обробку 3 метою ухвалення відповідного рішення. Маркетингові дослідження детермінують та/або корегують етапи прийняття рішень на підприємстві, що в результаті визначає 
отримання прибутку чи збитку від діяльності та, загалом, конкурентоспроможність компанії на ринку.

Протягом останніх років можна спостерігати незначне зростання обсягу маркетингових досліджень в грошовому вимірі на ринку України. Для повної детермінації галузевого розподілу та майбутніх трендів розвитку цього ринку доцільно доповнити класифікації маркетингових досліджень та з'ясувати взаємовплив на результати господарської діяльності.

Аналіз останніх досліджень $і$ публікацій. Маркетинговим дослідженням підприємств присвячено багато праць вітчизняних та зарубіжних авторів. Серед них роботи таких дослідників, як Лилик I. [3], Карасев А. [4], Гаркавенко С. [5], Старостіна [6], Решетілова Т. [7], Жегус О. [8] та багато інших вчених. Проте окремі питання щодо маркетингових досліджень у забезпеченні ефективної роботи підприємств потребують удосконалення та подальшого розвитку.

Mema cmammi полягає у дослідженні сутності маркетингових досліджень, узагальненні та доповненні їхньої класифікації, моніторингу ринку маркетингових досліджень в Україні та визначенні їхнього впливу на результати господарської діяльності підприємств.

Виклад основного матеріалу дослідження. Досліджуючи означену проблему зазначимо, що нині не існує єдиного визначення поняття «маркетингові дослідження».

Так, Ф. Котлер, Г. Армстронг вважають, що маркетингові дослідження це вид діяльності, який за допомогою інформації пов'язує споживача, покупця і громадськість 3 маркетингом; інформація, яку при цьому отримують, використовується для виявлення і визначення маркетингових можливостей i проблем; для вироблення, вдосконалення і оцінки маркетингових дій; для відслідковування результатів маркетингової діяльності, а також для покращання розуміння процесу управління маркетингом [1].

Міжнародний кодекс маркетингових досліджень визначає, що маркетингові дослідження - систематичний збір та інтерпретація інформації про осіб та організації, використовуючи статистичні та аналітичні методи для ухвалення нового чи підтримки прийнятого рішення [2].

Науковці Карасьов А. П., Гаркавенко С. вважають, що маркетингове дослідження - це збір, реєстрація, інтерпретація, обробка і аналіз інформації за різноманітними аспектам маркетингової діяльності [3, с. 16] 3 метою прийняття обгрунтованих маркетингових рішень» [4].

Згідно $з$ твердженням Старостіної А., маркетингові дослідження - це систематичний процес постановки цілей дослідження, ідентифікації обсягів збору, аналізу об'єктивної інформації і розробки рекомендацій для прийняття конкретних управлінських рішень [5].

На нашу думку маркетингові дослідження - це процес виявлення проблеми, збору, ідентифікації та інтерпретації даних відповідно до поставленої мети дослідження для прийняття рішення чи підтвердження раніше ухваленого.

Важливу роль у проведенні маркетингового дослідження відіграє обрання критеріїв, напрямків та типу дослідження. Відсутність єдиної думки науковців щодо цього питання пояснюється різними підходами щодо проведення маркетингових досліджень, цілей та бажаних результатів. 
Т. Б. Решетілова вважає, що маркетингове дослідження - це майже завжди комплексне дослідження, оскільки неможливо відокремити такі об'єкти дослідження як ринок, споживач, конкуренти. Ринок неможливо уявити без конкурентної боротьби, а поведінка споживача залежить від конкретних факторів ринкового середовища. Класифікація напрямів і об'єктів маркетингових досліджень за певними ознаками допомагає ефективній організації i управлінню процесом всього дослідження. Систематизована класифікаційна структура за класами або групами дозволяє досліднику набагато простіше оперувати з об'єктами, обираючи для кожного з них найбільш придатні методи та інструменти, що є в його розпорядженні [6].

Відповідно до змісту маркетингової діяльності компанії в процесі іiі взаємодії з навколишнім економічним середовищем, напрями маркетингових досліджень можуть бути класифіковані на три основні групи: дослідження ринку в цілому і його окремих суб'єктів (споживачі, конкуренти, постачальники, посередники); дослідження застосування компанією маркетингових інструментів (товар, ціна, розподіл, просування); дослідження маркетингового середовища (зовнішнього і внутрішнього) [6].

Схожої думки дотримуються О. В. Жегус та Т. М. Парцирна, які пропонують при проведенні маркетингового дослідження здійснювати його за такими напрямками: дослідження ринку, споживача, маркетингового середовища, маркетингової діяльності, конкурентів, ціни, реклами та збуту [7, c. 16-17].

При цьому, Карасьов А. П. виділяе дві інші групи маркетингових досліджень залежно від інструмента комплексу маркетингу та від предмета дослідження. Отже, можна виокремити дослідження товару (тест концепції, позиціонування та сегментації), ціни (психологічна ціна та ціновий аналіз), розподілу (мережа продажів та зона охоплення) й комунікації (тестування реклами та медіапланування). Поряд 3 тим, науковець класифікує дослідження залежно від предмета: для сегментування ринку; для розробки комунікацій; для розробки і реалізації реклами; дослідження обізнаності про рекламу та іiі результати, марочної назви, упаковки; цінове дослідження та тестування продукту [4, с. 25-32].

Ми вважаємо, що доцільно виділити класифікацію за предметом дослідження: дослідження ринку та контрагентів (споживачів, конкурентів; дослідження маркетингового середовища (зовнішнього та внутрішнього); дослідження комплексу маркетингового тиску (інструментів комунікаційної політики, ціновий вплив, політику розподілу та збуту). Вказана класифікація охоплює найбільш повний спектр діяльності підприємства, чинники та суб'єкти впливу на неї.

На наш погляд проведення маркетингових досліджень має носити систематичний та комплексний характер. Важливо виявити проблему та можливості для прийняття подальшого рішення, проте варто також розглядати маркетингові дослідження як послідовний та заздалегідь спланований процес 3 метою охоплення більшості аспектів досліджуваного об'єкта.

Ринок маркетингових досліджень в Україні в 2017 році зазнав суттєвих змін. Згідно з даними, опублікованими Українською Асоціацією Маркетингу 
(УАМ), оборот ринку маркетингових досліджень в 2017 році становив близько 992,07 млн грн або 35,35 млн дол [8]. Експертна оцінка УАМ обсягу ринку маркетингових досліджень наведена у таблиці 1 та на рисунку 1.

Таблиця 1

Обсяг ринку маркетингових досліджень у 2003-2017 pр:

\begin{tabular}{|c|c|c|c|c|}
\hline \multirow[t]{2}{*}{ Рік } & \multicolumn{2}{|c|}{ Обсяг ринку } & \multirow{2}{*}{$\begin{array}{c}\text { Прогнозоване } \\
\text { значення } \\
\text { зростання у дол. } \\
\text { США, \% }\end{array}$} & \multirow{2}{*}{$\begin{array}{c}\text { Зростання/падіння } \\
\text { дол. США, \% (за } \\
\text { даними компаній) }\end{array}$} \\
\hline & $\begin{array}{c}\text { \$ млн (згідно з } \\
\text { курсом } \\
\text { відповідного року) }\end{array}$ & млн грн & & \\
\hline 2003 & 14,6 & 77,3 & - & - \\
\hline 2004 & 19,5 & 100 & 20 & 34 \\
\hline 2005 & 24,8 & 127 & 25 & 27 \\
\hline 2006 & 33,5 & 169 & 20 & 35 \\
\hline 2007 & 41,5 & 212 & 24 & 31 \\
\hline 2008 & 55 & 275 & 28 & 18 \\
\hline 2009 & 45 & 304 & -5 & -22 \\
\hline 2010 & 40,5 & 324 & 24,5 & -10 \\
\hline 2011 & 44,4 & 354,6 & 12 & 10 \\
\hline 2012 & 56,95 & 449,24 & 10 & 26,70 \\
\hline 2013 & 60,8 & 487,1 & 25 & 8,4 \\
\hline 2014 & 42,44 & 509,29 & 25 & $-30,2$ \\
\hline 2015 & 35,9 & 767 & +51 & -13 \\
\hline 2016 & 32,33 & 865,14 & 20 & $-9,9$ \\
\hline 2017 & 35,35 & 992,07 & - & $+9,3$ \\
\hline
\end{tabular}

Джерело: [8].

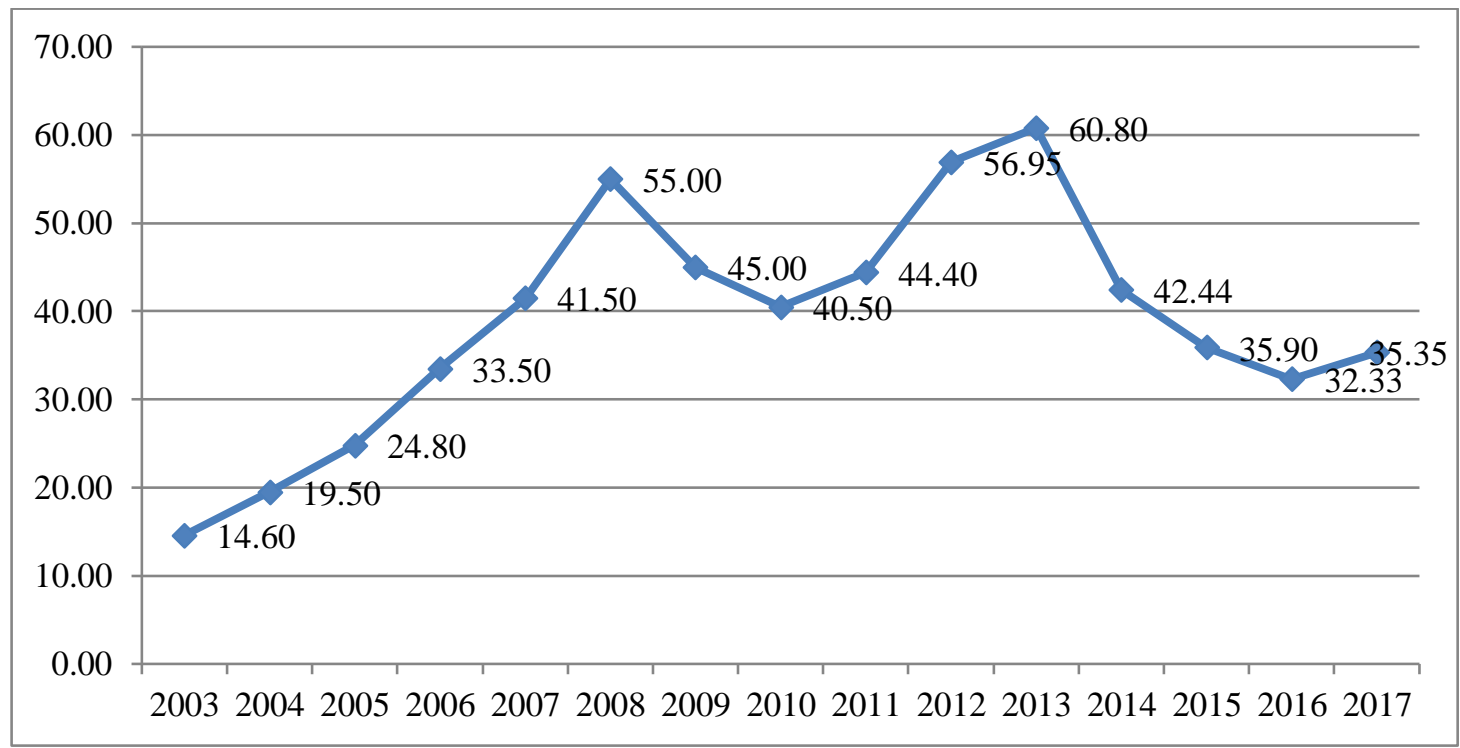

Рис. 1. Обсяг ринку маркетингових досліджень у 2003-2017 pр., дол. США Сформовано автором на основі джерела [8].

Результати проведеного аналізу свідчать про те, що пікові обсяги ринку маркетингових досліджень спостерігалися в 2008 та 2013 рр., при цьому найменша позначка 32,3 млн грн була в 2016 році. Варто зауважити, що у гривневому вимірі обсяг ринку зростав протягом всього досліджуваного періоду. 
Проте, враховуючи зростаючий показник інфляції, проаналізуємо обсяг ринку маркетингових досліджень в еквіваленті дол США. Результати проведеного аналізу свідчать про загальне зростання ринку на 9,3\% у 2017 році порівняно 3 попереднім.

Результати проведеного аналізу свідчать про зростання попиту у суб'єктів господарювання на проведення маркетингових досліджень. Проаналізуємо загальний обсяг маркетингових досліджень у розрізі спеціалізації їх основних замовників. Умовно сферу маркетингових досліджень поділяють на В2B (business to business) та В2C (business to customers). Як свідчать результати аналізу, споживчий ринок стабільно залишається основним замовником маркетингових досліджень (табл. 2).

Таблиця 2

Галузевий розподіл замовлень на маркетингові дослідження

\begin{tabular}{|c|c|c|c|c|c|}
\hline \multirow[t]{2}{*}{ № } & \multirow[t]{2}{*}{ Галузь } & \multicolumn{2}{|c|}{2016} & \multicolumn{2}{|c|}{2017} \\
\hline & & тис. грн & $\%$ & тис. грн & $\%$ \\
\hline 1 & B2C & 854622 & 70,25 & 613343 & 72,41 \\
\hline \multirow[t]{7}{*}{2} & \multirow{7}{*}{$\begin{array}{l}\text { Товари широкого вжитку: } \\
\text { Пиво та слабоалкогольні напої } \\
\text { Кондитерські вироби } \\
\text { Харчова промисловість інша } \\
\text { Парфумерія/гігієна } \\
\text { Тютюнові вироби } \\
\text { Інші }\end{array}$} & 57616 & 4,74 & 328525 & 38,79 \\
\hline & & 19778 & 1,63 & 24940 & 2,95 \\
\hline & & 1422 & 0,12 & 24769 & 2,92 \\
\hline & & 112494 & 9,25 & 113448 & 13,40 \\
\hline & & 40915 & 3,36 & 50318 & 5,94 \\
\hline & & 47858 & 3,93 & 69417 & 8,20 \\
\hline & & 2132 & 1,30 & 45633 & 5,39 \\
\hline 3 & Товари довготривалого використання & 9406 & 0,77 & 80432 & 9,50 \\
\hline 4 & Фармацевтика & 27012 & 2,22 & 27924 & 3,30 \\
\hline 5 & Автомобільний ринок & 9083 & 0,75 & 9562 & 1,13 \\
\hline 6 & 3MI & 12896 & 1,06 & 35728 & 4,22 \\
\hline 7 & Інші & 106219 & 8,73 & 131072 & 15,48 \\
\hline 8 & B2B & 197309 & 16,22 & 233561 & 27,58 \\
\hline 9 & Промисловість & 1805 & 0,15 & 3665 & 0,43 \\
\hline 10 & Гуртова та роздрібна торгівля & 5826 & 0,48 & 5287 & 0,62 \\
\hline 11 & Фінанси & 3133 & 0,26 & 2688 & 0,32 \\
\hline 12 & Банки & 1139 & 0,094 & 5961 & 0,70 \\
\hline \multirow[t]{2}{*}{13} & Страхові компанії & 412 & 0,034 & 2128 & 0,25 \\
\hline & Інші фінанси & & & 560 & 0,07 \\
\hline 14 & Енергетика та сировинні галузі & 1018 & 0,084 & 2158 & 0,25 \\
\hline 15 & Телекомунікації, поштовий сервіс & 9721 & 0,80 & 10063 & 1,19 \\
\hline 16 & Державні установи & 2148 & 0,18 & 3206 & 0,38 \\
\hline 17 & Громадські організації & 2890 & 0,24 & 13162 & 1,55 \\
\hline 18 & Рекламні агенції & 736 & 0,06 & 579 & 0,07 \\
\hline 19 & Дослідницькі інституції & 3193 & 0,26 & 19285 & 2,28 \\
\hline 20 & Ринок нерухомості & 1874 & 0,15 & 424 & 0,05 \\
\hline 21 & Будівництво & 1606 & 0,13 & 89 & 0,01 \\
\hline 22 & Дослідження Інтернету & 681 & 0,06 & 2179 & 0,26 \\
\hline 23 & Інші типи кліснтів & 2259 & 0,19 & 4086 & 0,48 \\
\hline 24 & $\begin{array}{l}\text { В т.ч. фармацевтика - ліки, що продаються за } \\
\text { рецептами }\end{array}$ & 126721 & 10,42 & 158021 & 18,66 \\
\hline 25 & Разом & 1216553 & 100 & 846904 & 100 \\
\hline
\end{tabular}

Джерело: [8]. 
На цьому ринку традиційно велику роль відіграють компанії харчової промисловості, виробники пива та слабоалкогольних напоїв, парфумерна промисловість [8]. Варто зазначити, що загальна сума і сума окремих досліджень за ринками В2С і В2В різниться, оскільки методика УАМ передбачає галузевий розподіл згідно 3 міжнародними нормами. Тому підрахунок відбувається за наданими компаніями показниками та відповідно до тієї сфери, до якої вони належать за власним переконанням замовника.

Результати проведеного дослідження свідчать про те, що найбільшу питому вагу на ринку маркетингових досліджень займають дослідження споживчого ринку. Так, у 2016 році майже 10\% становили дослідження для харчової промисловості, у 2017 році - категорія зросла до 13,4\% за рахунок перерозподілу у загальній структурі. Значний приріст показали також виробники тютюнових виробів з 3,23\% до 8,20\%. Майже 15\% у 2017 році становить категорія «послуги мобільного зв'язку, видавництва, господарська група, послуги, технологічний сектор, соціально-політичний сектор».

У галузевому розподілі маркетингових досліджень ринок В2В займає порівняно малу частку, проте у 2017 вона становила вже 27,58\%, що на 11\% переважає аналогічний показник 2016 року. Значного зростання досягла фармацевтика з 10,4\% у 2016 році до 18,7\% у 2017 році.

На тлі збільшення кількості маркетингових досліджень для крупних підприємств, спостерігається стійка тенденція до активізації діяльності у сфері маркетингових досліджень підприємствами малого та середнього бізнесу, які переважно користуються послугами синдикативних агенцій, котрі проводять панельні дослідження на постійній основі. Такий попит характеризується відносно низькою ціною таких досліджень, проте спостерігається чітка тенденція до розширення кола послуг і у сфері індивідуальних замовлень.

Таблиця 3

Чистий прибуток (збиток) підприємств за видами економічної діяльності у 2017 році, млн грн

\begin{tabular}{|l|r|r|r|r|r|}
\hline & \multirow{2}{*}{$\begin{array}{c}\text { Чистий } \\
\text { прибуток } \\
\text { (збиток) }\end{array}$} & \multicolumn{2}{|c|}{$\begin{array}{c}\text { Підприємства, } \\
\text { які одержали прибуток }\end{array}$} & \multicolumn{2}{|c|}{$\begin{array}{c}\text { Підприємства, які } \\
\text { одержали збиток }\end{array}$} \\
\cline { 5 - 7 } & $\begin{array}{c}\text { у \% до } \\
\text { загальної } \\
\text { кількості } \\
\text { підпр-в }\end{array}$ & $\begin{array}{c}\text { фінансовий } \\
\text { результат }\end{array}$ & $\begin{array}{c}\text { у \% до } \\
\text { загальної } \\
\text { кількості } \\
\text { підпр-в }\end{array}$ & $\begin{array}{c}\text { фінансовий } \\
\text { результат }\end{array}$ \\
\hline Усього & $\mathbf{1 6 8 7 5 2 , 8}$ & $\mathbf{7 2 , 4}$ & $\mathbf{5 1 5 4 6 0 , 6}$ & $\mathbf{2 7 , 6}$ & $\mathbf{3 4 6 7 0 7 , 8}$ \\
\hline $\begin{array}{l}\text { сільське, лісове та рибне } \\
\text { господарство }\end{array}$ & 68858,5 & 86,2 & 89411,9 & 13,8 & 20553,4 \\
\hline промисловість & 56124,0 & 71,4 & 195352,2 & 28,6 & 139228,2 \\
\hline будівництво & $-5014,3$ & 71,0 & 8925,9 & 29,0 & 13940,2 \\
\hline $\begin{array}{l}\text { оптова та роздрібна } \\
\text { торгівля; ремонт } \\
\text { автотранспортних } \\
\text { засобів і мотоциклів }\end{array}$ & 25874,2 & & & & \\
\hline $\begin{array}{l}\text { транспорт, складське } \\
\text { господарство, поштова } \\
\text { та кур'єрська діяльність }\end{array}$ & $-16796,7$ & 74,9 & 75740,6 & 25,1 & 49866,4 \\
\hline
\end{tabular}


Продовження табл. 3

\begin{tabular}{|c|c|c|c|c|c|}
\hline $\begin{array}{l}\text { тимчасове } \\
\text { розміщування й } \\
\text { організація харчування }\end{array}$ & 1773,5 & 69,3 & 4034,3 & 30,7 & 2260,8 \\
\hline $\begin{array}{l}\text { інформація та } \\
\text { телекомунікації }\end{array}$ & 12029,3 & 67,7 & 19564,3 & 32,3 & 7535,0 \\
\hline $\begin{array}{l}\text { фінансова та страхова } \\
\text { діяльність }\end{array}$ & 16806,6 & 62,8 & 25361,5 & 37,2 & 8554,9 \\
\hline $\begin{array}{l}\text { операції з нерухомим } \\
\text { майном }\end{array}$ & $-17551,2$ & 61,2 & 17910,7 & 38,8 & 35461,9 \\
\hline $\begin{array}{l}\text { професійна, наукова та } \\
\text { технічна діяльність }\end{array}$ & 32356,1 & 67,9 & 48091,7 & 32,1 & 15735,6 \\
\hline $\begin{array}{l}\text { діяльність у сфері } \\
\text { адміністративного та } \\
\text { допоміжного } \\
\text { обслуговування }\end{array}$ & $-3624,2$ & 67,7 & 5872,8 & 32,3 & 9497,0 \\
\hline освіта & 96,1 & 64,6 & 218,8 & 35,4 & 122,7 \\
\hline $\begin{array}{l}\text { охорона здоров'я та } \\
\text { надання соціальної } \\
\text { допомоги }\end{array}$ & 145,0 & 64,2 & 909,7 & 35,8 & 764,7 \\
\hline $\begin{array}{l}\text { мистецтво, спорт, } \\
\text { розваги та відпочинок }\end{array}$ & $-2300,4$ & 60,3 & 477,2 & 39,7 & 2777,6 \\
\hline $\begin{array}{l}\text { надання інших видів } \\
\text { послуг }\end{array}$ & $-23,7$ & 67,6 & 190,0 & 32,4 & 213,7 \\
\hline
\end{tabular}

Джерело:[9].

Збільшення кількості проведених маркетингових досліджень позитивно вплинуло на кількість суб'єктів господарювання, які досягли позитивний результат від господарської діяльності. Так у 2017 році 72,4\% підприємств отримали прибуток загальною сумою 515460,6 млн грн (табл. 3) [9].

3 метою виявити впливу зростання питомої ваги проведених підприємствами маркетингових дослідження у 2017 році доцільно згрупувати фінансові результати з аналогічними галузями, які є замовниками досліджень. У таблиці 4 подана зведена інформація за видами економічної діяльності (для галузей-замовників маркетингових досліджень були встановлені аналогічні сфери за КВЕД).

Таблиця 4

Зведені дані частки замовлень та фінансового результату за видами економічної діяльності протягом 2016-2017 рр.

\begin{tabular}{|c|c|c|c|c|c|c|}
\hline \multirow[t]{2}{*}{ № } & \multirow[t]{2}{*}{ Галузь } & \multicolumn{2}{|c|}{$\begin{array}{c}\text { Частка замовлень } \\
\text { марк. досл., \% }\end{array}$} & \multirow{2}{*}{$\begin{array}{l}\text { Відхилення } \\
\text { (+/-), \% }\end{array}$} & \multicolumn{2}{|c|}{ 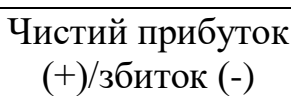 } \\
\hline & & 2016 & 2017 & & 2016 & 2017 \\
\hline 1 & Промисловість & & & & - & + \\
\hline & Товари широкого вжитку: & 4,74 & 38,79 & 34,05 & & \\
\hline & $\begin{array}{l}\text { Пиво та } \\
\text { слабоалкогольні напої }\end{array}$ & 1,63 & 2,95 & 1,32 & & \\
\hline & Кондитерські вироби & 0,12 & 2,92 & 2,8 & & \\
\hline & $\begin{array}{l}\text { Харчова } \\
\text { промисловість інша }\end{array}$ & 9,25 & 13,40 & 4,15 & & \\
\hline & Парфумерія/гігієна & 3,36 & 5,94 & 2,58 & & \\
\hline & Тютюнові вироби & 3,93 & 8,20 & 4,27 & & \\
\hline
\end{tabular}


Продовження табл. 4

\begin{tabular}{|c|c|c|c|c|c|c|}
\hline & Інші & 1,30 & 5,39 & 4,09 & & \\
\hline & $\begin{array}{l}\text { Товари довготривалого } \\
\text { використання }\end{array}$ & 0,77 & 9,50 & 8,73 & & \\
\hline & Фармацевтика & 2,22 & 3,30 & 1,08 & & \\
\hline & $\begin{array}{l}\text { В т.ч. фармацевтика - ліки, } \\
\text { що продаються за рецептами }\end{array}$ & 10,42 & 18,66 & 8,24 & & \\
\hline & Промисловість & 0,15 & 0,43 & 0,28 & & \\
\hline & $\begin{array}{l}\text { Енергетика та сировинні } \\
\text { галузі }\end{array}$ & 0,084 & 0,25 & 0,166 & & \\
\hline 2 & Будівництво & $\mathbf{0 , 1 3}$ & $\mathbf{0 , 0 1}$ & $-0,12$ & - & - \\
\hline \multirow[t]{3}{*}{3} & $\begin{array}{l}\text { Оптова та роздрібна } \\
\text { торгівля; ремонт } \\
\text { автотранспортних засобів і } \\
\text { мотоциклів }\end{array}$ & & & & - & + \\
\hline & Автомобільний ринок & 0,75 & 1,13 & 0,38 & & \\
\hline & Гуртова та роздрібна торгівля & 0,48 & 0,62 & 0,14 & & \\
\hline \multirow[t]{2}{*}{4} & $\begin{array}{l}\text { Транспорт, складське } \\
\text { господарство, поштова та } \\
\text { кур'срська діяльність }\end{array}$ & & & & + & - \\
\hline & $\begin{array}{l}\text { Телекомунікації, поштовий } \\
\text { сервіс* }\end{array}$ & 0,80 & 1,19 & 0,39 & & \\
\hline \multirow[t]{2}{*}{5} & $\begin{array}{l}\text { Інформація та } \\
\text { телекомунікації }\end{array}$ & & & & + & + \\
\hline & 3MI & 1,06 & 4,22 & 3,16 & & \\
\hline \multirow[t]{5}{*}{6} & $\begin{array}{l}\text { Фінансова та страхова } \\
\text { діяльність }\end{array}$ & & & & - & + \\
\hline & Фінанси & 0,26 & 0,32 & 0,06 & & \\
\hline & Банки & 0,094 & 0,70 & 0,606 & & \\
\hline & Страхові компанії & 0,034 & 0,25 & 0,216 & & \\
\hline & Інші фінанси & & 0,07 & 0,07 & & \\
\hline \multirow[t]{2}{*}{7} & $\begin{array}{l}\text { Операції } 3 \text { нерухомим } \\
\text { майном }\end{array}$ & & & & - & - \\
\hline & Ринок нерухомості & 0,15 & 0,05 & $-0,1$ & & \\
\hline \multirow[t]{4}{*}{8} & $\begin{array}{l}\text { Професійна, наукова та } \\
\text { технічна діяльність }\end{array}$ & & & & + & + \\
\hline & Рекламні агенції & 0,06 & 0,07 & 0,01 & & \\
\hline & Дослідницькі інституції & 0,26 & 2,28 & 2,02 & & \\
\hline & Дослідження Інтернету & 0,06 & 0,26 & 0,2 & & \\
\hline \multirow[t]{3}{*}{9} & $\begin{array}{l}\text { Надання інших видів } \\
\text { послуг** }\end{array}$ & & & & + & - \\
\hline & Громадські організації & 0,24 & 1,55 & 1,31 & & \\
\hline & Інші типи клієнтів & 0,19 & 0,48 & 0,29 & & \\
\hline
\end{tabular}

*Вказана група замовників належить до обох категорій: «транспорт, складське господарство, поштова та кур'єрська діяльність» і «інформація та телекомунікації»

Сформовано автором на основі джерел [8,9].

Промисловість охоплює товари широкого вжитку, довготривалого використання, фармацевтика та енергетика. Цей вид діяльності показав зростання частки маркетингових досліджень за всією галуззю, одночасно можна спостерігати і отримання прибутку підприємства у 2017 році. 
Остання категорія «надання інших видів послуг» містить тільки ті групи замовників, які відповідають КВЕДу. «Інші В2С» та «державні установи» не враховані, оскільки є кумулятивними групами з нечітко розмежованими сферами діяльності, що спричиняє дублювання часток проведених маркетингових досліджень в результаті.

Результати проведеного дослідження свідчать про наявність зв'язку між проведеними маркетинговими дослідженнями та збільшенням прибутку на підприємствах таких галузей: промисловості; оптової та роздрібної торгівлі; інформації та телекомунікації; фінансової та страхової діяльності; професійної, наукової та технічної діяльності.

Висновки та подальші перспективи розвитку. Маркетингові дослідження забезпечують ефективне функціонування компанії на ринку через виявлення проблеми, пошуку та збору відповідних даних з метою ухвалення рішення. Відповідно до класифікації вітчизняних та зарубіжних науковців можна виділити маркетингові дослідження в розрізі напрямів дослідження, використовуваних маркетингових інструментів та предметів дослідження. Для визначення ефективності функціонування підприємств доцільно розглядати маркетингові дослідження відповідно до категорії замовників - В2В та В2С, або за галузевим розподілом.

Зростання ринку маркетингових досліджень в Україні протягом останніх років свідчить про поступове нарощування попиту та зростання їхньої ролі для сучасних підприємств. Найбільшу частку серед замовників мають компанії, які працюють на споживчому ринку. Перспективними замовниками на проведення маркетингових досліджень $є$ підприємства малого та середнього бізнесу. Зростання як за частками, так і в грошовому обсязі більшості категорій видів діяльності корелює з отриманням прибутку відповідними галузями у 2017 році. Отже, маркетингові дослідження заслуговують підвищеної уваги 3 боку підприємств для ухвалення рішення щодо всього маркетингового комплексу та його елементів.

\section{Лimepamyра:}

1. Лилик I. Ринок маркетингових досліджень в Україні в 2014 році: експертна оцінка та аналіз УАМ. Маркетингові дослідження. 2015. № 1. С. 4-26.

1. ICC/ESOMAR International Code on Market and Social Research Mode of access: URL: https://cdn.iccwbo.org/content/uploads/sites/3/2008/01/ESOMARINTERNATIONAL-CODE-ON-MARKET-AND-SOCIAL-RESEARCH.pdf.

2. Карасев А. Маркетинговые исследования: учебник и практикум для СПО М.: Юрайт, 2016. 323 с.

3. Гаркавенко С. Маркетинг: підручник для студ. екон. спец. Вищих навч. закладів 6-те вид., доп. К.: Лібра, 2008. 720 с.

4. Старостіна А. Маркетинг: підручник / за ред. А.О. Старостіної. Київ: Знання, 2009. 1070 с.

5. Решетілова Т. Маркетингові дослідження: підручник: М-во освіти і науки України, Нац. гірн. ун-т. Електрон. текст. дані. Дніпропетровськ: НГУ, 2015. 357c. URL: http://mk.nmu.org.ua. 
6. Жегус О. Маркетингові дослідження :навчальний посібник Х.: ФОП Іванченко І.С., 2016. 237 с.

7. Лилик I. Ринок маркетингових досліджень в Україні 2017 рік: експертна оцінка та аналіз УАM Маркетинг в Україні. 2018. №1. C. 4-26 URL: http://uam.in.ua/upload/iblock/f9d/f9d7f27ec907c4d1f18dcf61173842ac.pdf.

8. Чистий прибуток (збиток) підприємств за видами економічної діяльності у 2017 році. Державна служба статистики України URL: http://www.ukrstat.gov.ua/operativ/operativ2017/fin/chpr/chpr_ed/chpr_ed_u/chpr_ed _1217_u.htm.

\section{Reference:}

1. Lylyk, I. V. (2015). Rynok marketynhovuh doslidzhen v Ukraini v 2014 rotsi: ekspertna otsinka ta analiz UAM [The Ukrainian market of marketing research in 2014: expert estimation an analysis of UAM]. Marketynhovi doslidzhennia Marketing researches, vol.1, pp. 4-26

2. ICC/ESOMAR International Code on Market and Social Research (n.d.). cdn.iccwbo.org. Retrieved from https://cdn.iccwbo.org/content/uploads/ sites/3/2008/01/ESOMAR-INTERNATIONAL-CODE-ON-MARKET-ANDSOCIAL-RESEARCH.pdf.

3. Karasev, A. P. (2016) Marketinhovye isledovania [Marketing researches]. Moskow: Yurait. 323 p.

4. Garkavenko, S. S. (2008). Marketynh [Marketing]. Kyiv: Libra. 720 p.

5. Starostina, A. O. (2009). Marketynh [Marketing]. Kyiv: Znannia 1070 p.

6. Reshetilova, T. B. (2015). Marketynhovi doslidzhennia [Marketing researches]. (electronic journal) Dnipropetsovsk: NHU. 357p Retrieved from http://http://mk.nmu.org.ua [in Ukrainian].

7. Zhehus, O. V., \& Partsyrna, T. M. (2016). Marketynhovi doslidzhennia [Marketing researches]. Kharkiv: FOP Ivanchenko I. S. 237 p.

8. Lylyk, I. V. (2018). Rynok marketynhovuh doslidzhen v Ukraini v 2017 rotsi: ekspertna otsinka ta analiz UAM [The Ukrainian market of marketing research in 2017: expert estimation an analysis of UAM]. Marketynh v Ukraini - Marketing in Ukraine, vol 1, pp. 4-26. Retrieved from http:/uam.in.ua/upload/iblock/ f9d/f9d7f27ec907c4d1f18dcf61173842ac.pdf [in Ukrainian].

9. Chystyi prybutok (zbytok) pidpryiemstv za vydamy ekonomichnoi diialnosti u 2017 rotsi [Net profit (loss) of enterprises by types of economic activity in 2017]. (n.d.). ukrstat.gov.ua. Retrieved from http://www.ukrstat.gov.ua/operativ/ operativ2017/fin/chpr/chpr_ed/chpr_ed_u/chpr_ed_1217_u.htm [in Ukrainian].

It is generally recognized that marketing research determines and/or adjusts the decision-making stages at the enterprise, which ultimately determines the profit or loss from the activity. For a complete determination of the sectoral distribution and future trends of Ukrainian market development, it is advisable to supplement the classification of marketing research and to find out the mutual influence on the results of economic activity. 
The marketing research has been investigated by researchers, such as F. Kotler, S. Garkavenko, Y. Krykavskyy, I. Lylyk, T. Reshetilova, A. Starostina. However, some aspects of marketing research for ensuring the effective operation of enterprises need to be improved and further developed.

The goal of the article is to study the nature of marketing research, generalize and add classification. Besides, the aim is to determine and to monitor market research in Ukraine and their impact on the results of economic activity of enterprises. In the article defined the marketing research as a process of recognizing a problem, collecting, identifying, and interpreting data.

The Ukrainian market of marketing research in 2017 has undergone significant changes. According to the Ukrainian Association of Marketing (UAM), the turnover of the market in 2017 amounted to about 992.07 million UAH. or $\$ 35.35$ million [8]. It was observed that Ukrainian market showed a general growth of the market by $9.3 \%$ in 2017 compared to the previous one.

The food industry, beer and low-alcohol beverage producers, and the perfume industry play significant role on the business-to-consumer (B2C) market. This market takes the largest share of marketing researches. Thus, in 2016, the category of the food industry had almost $10 \%$ in a whole structure; in 2017 the category has been increasing to $13.4 \%$. Producers of tobacco products showed a significant increase from $3.23 \%$ to $8.20 \%$.

In the sectoral distribution of marketing research, the B2B market has a relatively small share, but in 2017 it was already $27.58 \%$. The pharmaceutical industry has been growing significantly from $10.4 \%$ in 2016 to $18.7 \%$ in 2017 [8]. The existence of the link between the conducted marketing researches and increase of profit at the enterprises has been defined.

To summarize, the marketing researches ensure the effective functioning of the company in the market through the detection of problems, search, and collection of relevant data for decision making. It is appropriate to consider marketing research according to the category of customers - B2B and B2C, or by sectoral distribution. The growth of the Ukrainian market of marketing research has shown the gradual increase in demand, and the growth of its role for modern enterprises in the recent years. 